21. Хайтун С.Д. От эргодической гипотезы к фрактальной картине мира: Рождение и осмысление новой парадигмы. М.: Ленанд, 2016. $256 \mathrm{c}$.

22. Чехов А. П. Полное собрание сочинений и писем в 30 тт. Соч. Т. 8. М.: Наука, 1977. 528 с.

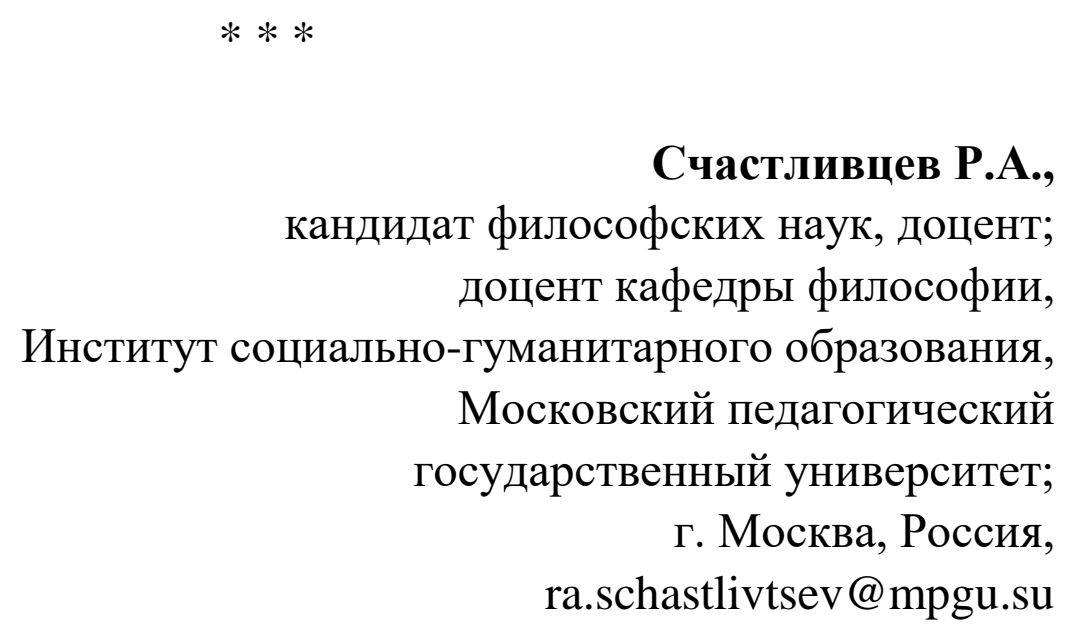

Философия образования в пост-современном обществе

Аннотация: в статье рассматриваются институциональные и идейные трансформации системы образования в пост-современном обществе. Данные изменения, прежде всего, связываются с информационными процессами в современном обществе. Сфера образования понимается в связи с этим, как информационно-образовательная среда. Пересматриваются некоторые фундаментальные классической концепции личности. На процесс современного образования оказывают непосредственное влияние такие характеристики пост-современного общества, как глобализация, нелинейность и неопределенность, риск, медиальность.

Ключевые слова: образование; пост-современное общество; информационное общество; глобализация; нелинейность; медиальность.

\title{
Roman Schaslivtsev,
}

Ph.D. in Philosophy, Associate Professor; Associate Professor of the Department of Philosophy, Institute of Social and Humanitarian education, Moscow Pedagogical State University; Moscow, Russia, ra.schastlivtsev@mpgu.su 


\title{
Philosophy of education in post-modern society
}

\begin{abstract}
: the article examines the institutional and ideological transformations of the education system in post-modern society. These changes are primarily associated with information processes in modern society. In this regard, the sphere of education is understood as an information and educational environment. Some fundamental classical concepts of personality are revised. It is pointed out that the process of modern education is directly influenced by such characteristics of post-modern society as globalization, nonlinearity and uncertainty, risk, mediality.
\end{abstract}

Keywords: education; post-modern society; information society; globalization; nonlinearity; mediality.

Свобода - это основной определяющий принцип функционирования пост-современного общества. Определяющий характер этого принципа был замечен в новое время. В трудах мыслителей этого периода от Р. Декарта до Г. Гегеля он выходит на первый план. В неклассической философии XIX-XX от Ф.Ницше до Ж. Деррида века свобода предстает как основополагающая категория.

В социальной реальности уровень свободы постоянно растет, выражаясь в усилении индивидуально-личностного начала. Это находит свое отражение в развитии классической либеральной идеологии (идеи юридического равенства, главенства прав человека, гражданского общества и правового государства) конкретным изменениям социальной структуры общества, уничтожению сословного неравенства. Следующими шагами в этом направлении стало распространение политических (избирательных) прав на все совершеннолетнее население, уравнивание в правах (в том числе политических) мужчин и женщин, разделение государства и церкви, передача государству, шире отражающему интересы общества, функции заключения и расторжения брака. Последнее становится ключевым моментом трансформации общества на пути к свободе. Брак и семья - основной институт традиционного общества, в XX веке подвергаются наиболее существенным изменениям. Свободное расторжение брака, легализация сожительства, уравнивание статуса брачных и внебрачных детей стали важными вехами на этом пути $[1 ; 2]$.

Однако, наряду с принципом свободы в обществе действует и противоположный принцип, который можно назвать принципом консервации. Он отражает фундаментальное гомеостатическое свойство социальной системы, как и любая система стремящейся к стабилизации своей 
структуры. Ответом на беспрецедентный рост свободы в XX веке стало появление тоталитарных режимов, изначально утверждавших передовые ее ценности. Парадоксально, но именно коммунистический режим в России изначально провозглашал чрезвычайно прогрессивное равенство сословий, полов, отделение государства от церкви, невиданное социальное равенство граждан. Однако, прогрессивные изменения довольно быстро компенсировались усилением консервирующего начала в лице государства. Вторая мировая война временно затормозила развитие свободы.

Движение к пост-современному обществу продолжилось после войны. Набирает силу гендерно-брачная (сексуальная) революция, намечается новая социальная тенденция - «революция меньшинств» и «революция маргиналов», то есть усиление социального влияния периферийных групп, образованных на основе несущественных для традиционного общества и общества модерна социальных признаков (детей и молодежи, нетрадиционных гендеров, «свободных» творческих профессий, этнических и религиозных маргиналов и т. д.) [4].

Таким образом, к концу XX в. наметились фундаментальные изменения в экономике, социальной структуре общества, общественном сознании, позволяющие сделать вывод о переходе к новому пост-современному обществу. Постараемся выделить основные черты этого общества.

«Современное» пост-современное общество - это общество рисков, то есть в его структуре и динамике заложен принцип, согласно которому вероятностное достижение более совершенных позиций требует определенных издержек. При этом существует прямая зависимость степени совершенства позиции от величины издержек и обратная от степени вероятности. Иными словами, чем совершеннее и сложнее цель, тем больше усилий требует ее достижение и менее вероятной оказывается [1].

Этот принцип становится основополагающим в обществе модерна с его идеологией капиталистического предпринимательства.

В пост-современном обществе принцип риска некоторым образом корректируется. Социальная активность, несомненно, остается важнейшей характеристикой пост-современной личности. Но она дополняется принципом устойчивого развития, который можно отнести ко всем социальным образованиям пост-современности. Последний предполагает оптимальное соотношение динамики и стабильности социальной системы, позволяющее избегать деструкции ее оснований в ходе непредсказуемого развития. Ключевым здесь оказывается понятие нелинейности. 
Для образования, как основополагающей сферы пост-современного общества это означает признание разнообразия форм реализации и организации образовательного процесса, его все большее освобождение, придание нелинейности. Например, постепенный отход от классно-урочной системы, сближение педагогического состава с коллективом учащихся, вовлечение последних, а также родителей и законных представителей в планирование и реализацию образовательного процесса [3; 5].

Если в традиционном обществе и обществе модерна ученик занимал подчиненное положение по отношению к личности педагога, то теперь их отношения все больше выравниваются. Позиция учителя, преподавателя становится менее доминирующей и авторитарной, он не предоставляет свои знания смиренно внимающему ученику, а содействует их образованию, возникновению параллельно с формированием его личности. При этом личность педагога продолжает формироваться. Он открыт диалогу, сам учится у ученика, со-образуется с ним.

Возникает перспектива пересмотра самого понятия личности. В школе понятие личности до сих пор трактуется однозначно позитивно, в духе эпохи просвещения. Каждый человек должен пройти процесс социализации и стать личностью, основные признаки которой - устойчивое мировоззренческое ядро и высокая социальная активность. При этом забывается, что в истории человечества сплошь и рядом встречаются негативные, разрушительные личности. Взгляды и убеждения тоже могут быть разного рода, также как и способы их отстаивания и другие виды социальной активности личности. Современное (пост-современное) толерантно-неагрессивное понимание личности предполагает, с одной стороны, уважительное отношение к другим личностям, их мнениям, даже если последние антагонистичны. При этом, правда, возникает парадокс свободы, свободы слова: если каждый может говорить, что хочет, то ктото может и молчать (молчаливое большинство). Свобода одной личности ограничена свободой другой личности, но слово может нарушать свободу, быть агрессивным, оказывать психологическое насилие [5].

С другой стороны, приветствуются социальный активизм и открытость. При этом возрастает невиданная ранее сознательная личностная неопределенность. Стремление избежать давления общества и абсолютизация принципа свободы приводит к тому, что человек пытается ускользнуть из системы социальных классификаций и типологий в область гендерной, культурной, этнической, религиозной неопределенности. 
Парадокс пост-современного общества заключается в том, что личностная идентичность проявляется в стремлении к личностной де-идентичности. На этот процесс указывали еще классики экзистенциализма. Личность пытается ускользнуть от социальной определенности. Разрыв с традиционным обществом знаменуется качественным усилением социальной свободы, когда выживание (в том числе и физическое) уже не зависит от принадлежности к какой-либо социальной группе. Оставаясь в социальной среде, личность вполне может не поддерживать непосредственные социальные контакты. Мало того, возрастает роль опосредованных социальных контактов, например, через интернет. При этом усиливается значимость «внутренней» социальности: личность самостоятельно выбирает группы, ассоциирование с которыми для нее оказывается наиболее комфортно, поддерживая последнее, пока степень комфорта остается на приемлемом для нее уровне. Все это усиливается тем, что пост-современное общество - это общество меньшинств. Большие и средние социальные группы при усилении социальной мобильности все меньше влияют на статус личности. Последняя свободно выбирает малую группу, наиболее полно соответствующая своей идентичности или, что еще более эффективно, сама создает ее.

Такой новой модели социальной медиальности должна соответствовать новая модель педагогической медиальности. Пост-современная педагогическая среда образуется в пространстве с максимальным количеством «степеней свободы», в котором реализует себя учащийся. То есть это должно быть пространство его условного взаимодействия с природой, обществом и самим собой, модель пространства формирования его опыта, максимально приближенная к «реальности» [6].

Для пост-современного общества характерно качественное повышение социальной мобильности личности, выражающееся прежде всего в изменении информационной мобильности. Последняя все меньше зависит от пространственной локализации. Можно получать, обрабатывать информацию, принимать решения на ее основе, реализовывать их, не меняя своего местоположения. Так называемое дистанционное образование перестало быть чем-то экзотическим. Наоборот, благодаря новейшим информационно-коммуникационным технологиям исчезает привязанность к определенной точке пространства, зданию, классу, аудитории, в которой должны сойтись учащийся и педагог. При этом образование оказывается частным случаем широкомасштабной информационной деятельности, жизни в информационной среде [5; 6]. 


\title{
Лuтература:
}

1. Бек У. Общество риска. На пути к другому модерну. М: Прогресс-Традиция, 2000. 384 с.

2. Буряк В.В. Глобальное гражданское общество и сетевые революции. Симферополь: Диайпи, 2011. 152 с.

3. Любарский Г.Ю. Образование будущего. Университетский миф и структура мнений об образовании XXI века. М: Едиториал УРРС, $2020.526 \mathrm{c}$.

4. Пфаненштиль И.А. Современные процессы глобализации и геополитические последствия: социально-философское осмысление. Монография. Красноярск: СФУ, 2013. 360 с.

5. Тузовский И.Д. Утопия XXI: глобальный проект «Информационное общество». Челябинск: Челяб. гос. акад. культуры и искусств, 2014. $392 \mathrm{c}$.

6. Ясвин В.A. Образовательная среда: от моделирования к проектированию. М.: Смысл, 2001. 365с.

\author{
$* * *$ \\ Шелковников А.Ю., \\ доктор философских наук, доцент; \\ профессор кафедры философии, \\ Институт социально-гуманитарного образования, \\ Московский педагогический \\ государственный университет; \\ г. Москва, Россия, \\ ayu.shelkovnikov@mpgu.su
}

\section{Проблемы современного преподавания философии в контексте общей психологии}

Аннотация: в статье говорится о необходимости психологической пропедевтики для преподавания философии в системе высшего образования. В качестве образца рассматривается система преподавания психологии и философии выдающегося русского философа Г.И. Челпанова (1862-1936). Статья может представлять интерес для философов, психологов, педагогов, студентов и аспирантов.

Ключевые слова: философия; психология; образование; пропедевтика. 